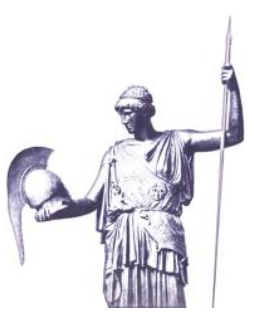

Connections: The Quarterly Journal

ISSN 1812-1101, e-ISSN 1812-2973

Себастьян фон Мюнхов, Connections QJ 19, no. 2 (2020): 5-10

https://doi.org/10.11610/Connections.rus.19.2.00

Влияние пандемии COVID-19 на безопасность

\title{
Последствия пандемии COVID-19 для безопасности
}

\section{Себастьян фон Мюнхов}

Европейский центр исследований по вопросам международной безопасности им. Джорджа К. Маршалла, https://www.marshallcenter.org

В начале марта 2020 года, примерно через два месяца после вспышки болезни в китайской провинции Ухань, COVID-19 поразил Западную Европу. В настоящее время до 5,7 миллиона человек во всем мире дали положительный результат на тест и более 350000 человек умерли. Только в Италии, Великобритании, Испании, Франции и Германии умерло более 135000 жителей. В начале кризиса европейские страны и США закрыли свои границы и замкнулись внутри себя, чтобы замедлить распространение вируса. Школы, университеты, розничная торговля и заведения общественного питания были закрыты. Когда было возможно, офисных сотрудников отправляли домой для удаленной работы, и с разной интенсивностью принимались законы и указы, делающие обязательным физическое дистанцирование. Поначалу в заголовках доминировали внутренние темы. Европейская общественность стала свидетелем того, как лица, принимающие политические решения, вместе с экспертами-вирусологами и эпидемиологами обсуждали какие шаги необходимы для снижения уровня заражения и обеспечения безопасности работников сектора здравоохранения, находящихся в контакте с пациентами. Западные либеральные демократии, в частности, оказались втянутыми в тройную проблему попытки спасти жизни своих жителей, иметь в виду беспрецедентные ограничения основных прав своих граждан и обеспечить экономическое выживание.

Поскольку COVID-19 застал большинство исследователей в области международной безопасности врасплох, в самые первые дни карантина влиянию вируса на международные отношения уделялось мало внимания. В 
первых работах рассматривалась роль Китая в пандемии. Некоторые авторы интересовались информационной политикой Пекина, другие ставили под сомнение организованные операции по оказанию помощи в Европе. Некоторые авторы указывали на опасность того, что голодный Китай поглотит обанкротившуюся экономику Европы после COVID, в то время как другие подробно фокусировались на агрессивной риторике, с помощью которой Китай пытался отвергнуть обвинения, связанные с происхождением вируса. В меньшей степени внимание уделялось и России, которая троллила европейскую общественность дезинформацией, пропагандистскими кампаниями оказания помощи и рекламой авторитарных методов, как превосходящих западные модели преодоления кризиса.

Расположенный в Гармиш-Партенкирхене Европейский центр исследований в области безопасности им. Джорджа К. Маршалла, являющийся оперативным центром Консорциума «Партнерство ради мира» (ПрМК), постигла та же участь, что и большинство учебных заведений в Центральной Европе. В считанные дни он приостановил свою деятельность, отменил курсы и поездки или делегации, участвующие в практических занятиях или семинарах за рубежом. Его сотрудников отправили домой для удаленной работы, и к середине-концу марта 2020 года преподаватели Колледжа исследований международной безопасности при Центре адаптировались к новому режиму работы. С тех пор в отдельном разделе о COVID-19 на сайте Центра были размещены более 20 статей. Большинство работ поступило от сотрудников Центра Маршалла, но также и от аффилированных авторов. Большинство работ было написано специально для сайта. Несколько статей, в основном аналитических, были размещены во внешних изданиях, а затем связаны ссылками с сайтом Центра. Основываясь на этом накопленном в последнее время опыте, сотрудники колледжа впоследствии организовали виртуальные онлайн-семинары для обсуждения различных аспектов коронавируса и международной безопасности с определенной интересующейся этой тематикой аудиторией из своей сети выпускников, насчитывающей 14000 участников.

С точки зрения содержания, фокус работ ученых из Центра Маршалла не отличался от описанной выше модели. Как и в случае с их зарубежными коллегами, их ранние работы были сфокусированы на так называемом Соперничестве великих держав. Опубликованные статьи о дистанцировании от Китая или о роли Путина во время пандемии свидетельствуют о попытках думать о международных отношениях в рамках COVID параметров. Чуть позже, другие участники пролили свет на влияние вируса на конкретные регионы, то есть на Балканы или Центральную Азию. Затем авторы представили статьи о законности использования инструментов для борьбы с пандемией в национальном масштабе, а именно об использовании вооруженных сил или применении правовых инструментов для введения карантина. В других работах снова рассматривались темы, актуальные до коронавируса, 
такие как терроризм или насильственный экстремизм, и обсуждалось, вынуждает ли нас COVID-19 пересмотреть соответствующие оценки угроз. Таким образом, почти все направления возможностей Центра Маршалла для исследований по безопасности были использованы при рассмотрении влияния вируса на конкретные области компетентности.

Колледж был благодарен офису Консорциума «Партнерство ради мира» в Гармише, когда тот предложил опубликовать некоторые статьи в специальном печатном издании на тему «Влияние пандемии COVID-19 на безопасность». Результатом является следующая подборка из десяти рецензированных статей. Восемь статей были написаны сотрудниками Центра им. Маршалла. С согласия авторов и отдела публикаций Колледжа они были отделены от вышеописанной попытки предоставить мировой общественности анализ вируса и того, как он влияет на международные отношения. Работы в этом томе сгруппированы таким образом, что отражают более раннюю категоризацию. В них представлен ряд тем, связанных с международной и национальной безопасностью - терроризм, эффективное управление, региональные исследования и соперничество великих держав.

В ведущей статье, д-р Това Норлен обсуждает «Влияние COVID-19 на салафитско-джихадистский терроризм», ${ }^{1}$ тема, которая мало дискутировалась, когда пандемия распространилась по всему миру весной 2020 года. Возможно, фокус на внутренней сфере здравоохранения подавил осознание того, что угроза джихада не исчезнет во время кризиса с коронавирусом. Доктор Норлен взяла на себя смелость объяснить, как нынешний кризис может изменить основное послание и стратегию джихадистов-салафитов и, в свою очередь, повлиять на вербовку, тактику, возможности, руководство и даже их доктрину.

Следует профессор Ральф Ролофф, заместитель декана Колледжа исследований по международной безопасности, с докладом под названием «COVID 19 и ничейный мир: влияние на Европейский Союз?». ${ }^{2}$ В частности, Ральф предлагает увязать экономическую поддержку в рамках пакета COVID-19 с демократическими ценностями, защитой гражданских прав, прав человека и верховенством закона.

Продолжает д-р Пал Дунай с рассуждениями об Европейском Союзе. Его работа «Пандемия коронавируса и реакции в странах, вступивших в ЕС в 2004-2007 гг.» представляет собой вклад, который объединяет региональ-

1 Tova Norlen, "The Impact of COVID-19 on Salafi-Jihadi Terrorism," Connections: The Quarterly Journal 19, no. 2 (2020): 11-23, https://doi.org/10.11610/ Connections.19.2.01.

2 Ralf Roloff, "COVID 19 and No One's World: What Impact for the European Union?" Connections: The Quarterly Journal 19, no. 2 (2020): 25-36, https://doi.org/10.11610/Connections.19.2.02. 
ные исследования по конкретному региону Европы, но также включает элементы эффективного управления. ${ }^{3}$ Д-р Дунай объясняет, почему государства Восточной и Центральной Европы противостояли пандемии коронавируса весной 2020 года лучше, чем многие другие страны, и как их правительства боролись за восстановление экономики и поддержание стандартов верховенства закона.

Моя статья «Правовая и законодательная борьба с COVID-19: прецедентное право Германии, связанное с комендантским часом» глубже исследует дилемму о том, как сохранить функционирование сектора здравоохранения, ограничивая основные свободы и сохраняя экономическую и производственную деятельность. ${ }^{4}$ Я пролил свет на некоторые решения административных судов в Германии, которые должны были согласовать эти цели.

Бывший министр обороны и нынешний руководитель Центра менеджмента безопасности и обороны Болгарской академии наук доктор Тодор Тагарев, уважаемый научный работник и друг ПрМК и Центра им. Маршалла, пишет о «Балансе задач обороны и задач в интересах гражданского населения: Влияние Covid-19 на роли болгарских военных». ${ }^{5}$ Его статью также можно рассматривать как вклад в области эффективного управления. В то время, как Пал и я рассматривали внутренний инструментарий, как важнейший элемент в борьбе с пандемией, Тодор обращается к силовому инструменту вооруженных сил и к тому, как его можно использовать для смягчения проблемы коронавируса.

Профессор Центра им. Маршалла Джек Л. Кларк добавляет к этому интересному аспекту более общую статью «Пандемии и вооруженные силы: какие роли подходят вооруженным силам?». ${ }^{6}$ Эти публикации дают хорошую возможность для сравнения авторитарных методов борьбы с пандемией с методами либеральных демократий.

Далее это специальное издание продолжается тремя работами, объединяющими темы соперничества великих держав и региональных исследований. В статье преподавателя Центра им. Маршалла доктора Петры Вейланд

3 Pál Dunay, "Coronavirus Pandemic and Reactions in the EU Accession Classes of 2004-2007," Connections: The Quarterly Journal 19, no. 2 (2020): 37-47, https://doi.org/10.11610/Connections.19.2.03.

4 Sebastian von Münchow, "The Legal and Legitimate Combat Against COVID-19: German Curfew-related Case Law," Connections: The Quarterly Journal 19, no. 2 (2020): 49-60, https://doi.org/10.11610/Connections.19.2.04.

5 Todor Tagarev, "Balancing Defense and Civil Support Tasks: The Impact of Covid19 on the Bulgarian Military's Roles," Connections: The Quarterly Journal 19, no. 2 (2020): 61-76, https://doi.org/10.11610/Connections.19.2.05.

6 Jack L. Clarke, "Pandemics and Armed Forces: Which Roles are Appropriate?" Connections: The Quarterly Journal 19, no. 2 (2020): 77-88, https://doi.org/10.11610/ Connections.19.2.06. 
«Пандемия на Ближнем Востоке и в Северной Африке: размышления о текущих и будущих последствиях» содержится довольно мрачный прогноз для рассматриваемого региона. ${ }^{7}$

Доктор Грег Глисон из колледжа в Гармише и профессор Куралай Байзакова (кафедра международных отношений и мировой экономики Казахского национального университета им. Аль-Фараби, Алматы, Казахстан) пишут о «COVID-19 в Центрально-азиатском регионе: Национальные ответные меры и региональные последствия». ${ }^{8}$ Этот регион вызывает особый интерес, поскольку пять его государств находятся в непосредственном соседстве с Китаем и Россией. Таким образом, они сталкиваются с двумя ревизионистскими силами, стремящимися к политическому и экономическому господству в регионе.

Говоря об этом, Фрэнк Моуриц, академический координатор магистерской программы исследований в области безопасности в Центре им. Маршалла, пишет о «Последствиях пандемии COVID-19 для китайской инициативы 'Один пояс, один путь' ». ${ }^{9}$ Он призывает государства вдоль нового Шелкового пути опасаться попыток Пекина переименовать свою так называемую инициативу «Дипломатия масок» в проект «Дорога здоровья».

И наконец последнее, но не по значению, Исследовательская группа ПрМК по региональной стабильности в Юго-Восточной Европе (ИГ РСЮВЕ) делится со своими читателями статьей «Страны Западных Балкан перед лицом пандемии COVID-19: рекомендации по политике». ${ }^{10}$ Рекомендации в этой статье являются результатом Первой виртуальной встречи РСЮВЕ, состоявшейся 28 мая 2000 г. Они содержат ряд реалистических предложений для правительств Западных Балкан, а также для ЕС, стран-членов ЕС и НАТО и лиц, принимающих решения о том, как противостоять коронавирусу и вызовам, связанным с безопасностью, в Юго-Восточной Европе.

Все статьи в этом томе были написаны в конкретном контексте весны / начала лета 2020 года, фазы, когда либеральные демократии начали осторожно осуществлять повторную либерализацию общественной жизни. Но ограничения все еще сохраняются, оказывая влияние на воздушное сообщение, торговлю, своевременное производство, академический обмен и

7 Petra Weyland, "The Pandemic in the Middle East and North Africa: Reflections on Current and Future Impacts," Connections: The Quarterly Journal 19, no. 2 (2020): 89-99, https://doi.org/10.11610/Connections.19.2.07.

8 Greg Gleason and Kuralay Baizakova, "COVID-19 in the Central Asian Region: National Responses and Regional Implications," Connections: The Quarterly Journal 19, no. 2 (2020): 101-114, https://doi.org/10.11610/Connections.19.2.08.

9 Frank Mouritz, "Implications of the COVID-19 Pandemic on China's Belt and Road Initiative," Connections: The Quarterly Journal 19, no. 2 (2020): 115-124, https://doi.org/10.11610/Connections.19.2.09.

10 Study Group Regional Stability in South East Europe, "Policy Recommendations: The Western Balkan Countries in the Face of the COVID-19 Pandemic," Connections: The Quarterly Journal 19, no. 2 (2020): 125-131, https://doi.org/10.11610/ Connections.19.2.10. 
другие. Статьи были представлены в момент, когда западные правительства и надправительственные организации, такие как Европейский Союз, сформировали несколько больших пакетов восстановления. Ни в одной из статей не утверждается, что сделанные наблюдения и выводы не могут быть обессилены второй - возможно, даже худшей - волной COVID-19 или национальными политическими волнениями, меняющими курс нации. Следовательно, эти статьи следует читать в историческом контексте с марта по май 2020 года. Тем не менее, статьи затрагивают большое количество аспектов, связанных с коронавирусом, в международных исследованиях по вопросам безопасности. Это специальное издание Connections раскрывает раннее инстинктивное ощущение теоретиков, изучающих вопросы безопасности, которые помнят, что такие явления, как терроризм, не исчезнут из-за пандемии, создают контр-нарративы, проливающие свет на попытки авторитарных режимов дискредитировать западные модели и призывают наши правительства придерживаться стандартов верховенства закона при борьбе с вирусом. В двух словах, авторы иллюстрируют то, что десять признанных экспертов сочли важным и заслуживающим внимания.

Сотрудники Консорциума «Партнерство ради мира», редакторы, рецензенты и авторы желают читателям крепкого здоровья и безопасности при чтении этого специального выпуска о пандемии и ее влияния на международные дела.

июнь 2020

\section{Отказ от ответственности}

Выраженные здесь взгляды являются исключительно взглядами автора и не отражают точку зрения Консорциума оборонных академий и институтов изучения безопасности ПрМ, участвующих организаций или редакторов Консорциума.

Издание Connections: The Quarterly Journal, том 19, 2020 осуществляется при поддержке правительства Соединенных Штатов.

\section{Об авторе}

Себастьян фон Мюнхов - смотри CV на с. 66 этого издания, https://doi.org/10.11610/Connections.rus.19.2.04. 